\title{
THE RELIGIOUS TOLERANCE IN MEDIEVAL SPAIN
}

\author{
Marija TASHEVA \\ Professor in pension, Ss Cyril and Methodius University of Skopje \\ E-mail: marijataseva41@yahoo.com
}

\begin{abstract}
The aim of this paper is, through a comparative analysis of the attitude towards the Jews and later towards the Muslims in the Christian part, and the attitude towards the Jews and the Christians in the Muslim part of medieval Spain, to perceive the capacities for a religious tolerance of both religions in this area. The focus of the analysis is on the conditions regarding the religious tolerance in Visigoth Spain, the Omayyad Caliphate and the Christian principalities in the Reconquista period. The text relies on, for the most part, on the evidence from three classic works of Jewish historiography: The Jews in Moslem Spain by Eliyahu Ashtor, A History of the Jews in Christian Spain by Yitzhak Baer, Jews, God and History by Max Dimont and also The History of Spain by Rafael Altamira y Crevea.
\end{abstract}

The starting point of the analysis is the presumption that the level of religious tolerance is to a large extent conditioned by the economic and political circumstances of the societies where different religious communities live rather than the necessity of these communities to retain their religious distinctiveness or impose it on others.

Key words: religious tolerance, Arianism, Catholicism, Islam, Jews, caliphate, Reconquista

Medieval Spain is a convenient environment for researching the religious tolerance considering that in the period from the eighth to the eleventh century of the European history, up to the beginning of the Crusades, it was the first and only environment where close contacts were maintained among representatives of the three monotheistic religions, with these relationships continuing into the next several centuries. The transition from Christian to Muslim and back to Christian rule, on the other hand, provides an opportunity for a comparative analysis of the attitude towards the other faiths in each of these rules. 
The religious tolerance here is observed from a religious and a political standpoint: religious acceptance on the part of the majority (i.e., the ruling) religious community that members of other faiths may freely practice their own religion and rituals; political respect, meaning the right of the members of other faiths to participate in the social life without setting up barriers based on their religious affiliation to access the social institutions.

\section{The religious tolerance in Visigoth Spain}

When the Visigoths established their kingdom on the territories of southwestern France and Iberian Spain in the fifth century, they had already adopted Christianity in an Arian version. Thus, at the very beginning of their reign, problems with differences in religion arose, the indigenous SpanishRoman population being Catholic. Considering the fact that the Catholics constituted the majority, the rulers had no other choice but to seek a solution in reconciliation of the two religious groups so as to prevent potential turmoil. In the spirit of what had been happening in Byzantium in similar situations, several councils were held in Toledo, the purpose of which was to find solutions to the dilemmas of a religious nature. The problem with the Christian diversity was resolved at the Second Council of Toledo (587 or 589), when King Reccared declared his acceptance of Catholicism. However, this did not lead to an outright transition to Catholicism. Followers of Arianism led several rebellions, but eventually victory was won by the Catholics. ${ }^{1}$ After that, the Councils of Toledo dealt with issues related to the status of the Jews.

The Jews settled on the Iberian Peninsula long before the arrival of the Goths, in the pre-Visigoth period and were not regarded as "stratum of foreign colonists but an indigenous element that adopted the customs of the other inhabitants of the land and lived according to their ways".

"The Jewish settlement on the Iberian Peninsula was a very ancient one and in its early stages had prospered. Even after the Visigoths had established their rule over the land, the condition of the Jewish communities remained favorable for a long time. They earned their livelihood with dignity, and they fulfilled the laws of the Torah and observed its commandments without hindrance" (Ashtor, 1992:11).

\footnotetext{
${ }^{1}$ According to Altamira y Crevea, those rebellions had a political rather than a religious motivation. Dissatisfaction was mainly instigated by the opportunities that were given to representatives of the indigenous people for acquiring the highest status (Altamira y Crevea, 1951: 65).

${ }^{2}$ Even in the period of survival of their kingdom, the Jews built a policy of tolerance in relation to members of other religions. To them "the social, cultural and economic interactions between Jews and non-Jews are, with few limitations, both acceptable and appropriate... in the real-life world of the community and marketplace, they are perfectly appropriate customers, business associates, and neighbors" (Neusner\&Chilton (Eds.), 2008:219).
} 
In the beginning of the Visigoth rule, the Jews conformed to the same regulations that applied to the indigenous Roman population. By the time of the Visigoths' transition in Catholicism, they were able to marry Christians, engage in social activities and be part of the administrative apparatus. They could even be provincial governors. However, their fate suddenly changed. "They were excluded from the natural social structure as it existed at the end of the Roman period" (Baer, 1992:20). From the Third Council of Toledo onward, at every following Council, decrees were adopted concerning the Jews, whose aim was "to institute laws to eradicate Judaism from the land" (Ashtor, 1992:11). In 616, a law was passed according to which Jews must convert or leave the land. The aftermath of this was the conversion of thousands of Jews, though thousands also left the country. ${ }^{3}$ After that, every ruler passed laws on the issue, some for alleviation of the previously adopted decrees with permission for conversion back to their original religion, others for their aggravation, with death threats unless they converted back to Catholicism. Still, regulations were also made with regards to the converts, known as Marranos, which degraded their social position, subjected them to strict control, forbade them to move freely in the territory. Consequently, in the dynastic wars, the Jews gave their support to the pretenders to the throne who promised them religious freedom. But even when victory was on the side of the one they supported, once he sat on the throne, he followed the policy of the eradication of the Jews from Spain. Thus, at the Twelfth Council of Toledo, a decision was made that "every Jew must convert within a year", that every one of them must go through a training for conversion in Christianity, and an obligation to snitch on the ones who violated the aforementioned regulations and were secretly practicing their religion. Additional regulations, which involved restrictions in the economic sphere, were to ensure implementation of these decisions. The next council, at the end of the same year, adopted a decision that all Jews will become slaves and will be given to Christian masters who will oversee their religious ritual; all Jewish children above the age of seven will be taken away from their parents and will be brought up in the Christian spirit and will be married to Christians; and all their property will be confiscated. Hence, it is not surprising that they quickly connect with the Muslim conquerors of Cordoba and accept recruitment into the Muslim army as it conquered the rest of the Visigothic cities. In addition to this they espoused the existing mentality of "if necessary to defend their lives and property by force" (Ashtor, 1992: 25).

\footnotetext{
${ }^{3}$ King Sesibut's edict of 616, among other things said: "Every Jew who would not be converted, and would not send his sons and servants to the priest, will receive 100 strikes on the back, will have his head shaved, will be banished forever from the realm, and all his property will remain in the king's possession. According to Altamira y Crevea, about 90000 Jews converted in Catholicism then. (Altamira y Crevea, 1951:66).
} 


\section{The religious tolerance in the Arab caliphate}

The reign of the Arabs on the Iberian Peninsula lasts for seven centuries, and within this time span there are discernible periods of adaptation, growth and gradual decline: the first century of the conquest is marked with internal conflicts among the occupying tribal groups, the following several centuries are characterized by establishing an order with a strong central government which attained a highly developed civilization, which was followed by the onset of a process of internal disintegration, accompanied by gradual diminishment of the central power, the splitting up of the caliphate into numerous principalities and their conquest by the Christian principalities from the north of the peninsula. During these periods changes occurred regarding the attitude of the central government towards the non-Muslim communities, the Christians and the Jews, although, as Altamira y Crevea observes, that did not affect directly the everyday relations among the members of the individual religious communities who were close and benevolent in the period from the $8^{\text {th }}$ to the $11^{\text {th }}$ century. ${ }^{4}$ Essentially, the Arabs allowed the conquered peoples the right to convert to Islam or to keep their religion, and in the latter case they had to pay a tax. ${ }^{5}$ However, the needs for additional funds at that time caused changes in the amount of the taxes, accompanied by reprisals towards those who were unable to pay, which led Altamira y Crevea to conclude that the recognition of the right to a religious distinctiveness had more of a political than a religious foundation (Altamira y Crevea, 1951:85).

When the Muslim conquest began on the peninsula, the Jews perceived it as a deliverance from the Christian oppression and they openly tried to help them. Hence, the Muslim conquerors, before embarking on further conquests, assigned them the role of a local militia, adding only a small number of Muslim soldiers. Thus, it was not necessary to engage a lot of soldiers in the conquered towns and villages, and this enabled such a rapid advance that when they reached the capital Toledo, there was no need to conquer it. The rulers, the wealthy citizens and the clergy had already abandoned it. This encouraged the Muslim army to advance further, but it was halted by the winter. According to

${ }^{4}$ Altamira y Crevea stresses that the official attitudes of the rulers towards the religious minorities should not be equated with the common relations of the members of the different religions who shared the same space - they socialized, established common trade connections, had a mutual respect for each other's customs and hence, the relations between the Muslims and the Christians in the period from the eighth to the eleventh century should be assessed very differently from those of the next epoch (Altamira y Crevea, 1951:101).

${ }^{5}$ When the Arabs established their rule in Spain and guaranteed everybody their religious freedom, the forcibly converted Jews from the Visigothic period the Marranos, could return to their faith. Yet, many of them did not do that, becoming, as Max Dimont observes, "cosmopolitan world citizens who moved with elegance and aplomb in the courts of viziers and grandees, marrying into the families of both". Later, they would fall victims to the Inquisition. (Dimont, 2003:219). 
Ashtor, they were also aided by the opponents of the ruling dynasty, who hoped in vain to take the throne, and by the indigenous Roman population. Thus, "the march of the conquest was accomplished with relatively little bloodshed" (Ashtor, 1992:19). The same disposition of the forces followed during the second wave of Muslim conquests, directed west to the previous one.

The Arab conquerors were a tribal people with no experience of living in cities, so shortly after their coming, they "did not attempt to upset the social order that had existed in Spain prior to their invasion" (Baer, 1992: 23). The Christians retained their language and customs which meant they wielded a cultural influence over the invaders who "themselves formed only a thin ruling stratum". Considering that the Christians were better educated, along with the Jews, they had various positions on the court of the caliph and in the state administration.

In the conquered cities, apart from returning their religious freedom and entrusting them with administrative positions, one of the policies regarding the Jews was to concentrate them in a particular part of the city, which was possible due to the vacant houses the wealthy citizens had left. All this incited a wave of returning of those who had earlier been banished to Africa, and a parallel intensive settling of Arab and Berber population. Thus, "Arabic Spain became a refuge for Jews" (Ibid., 24).

Still, "the honeymoon between the Moslem rulers of Spain and the inhabitants of the land did not last long" (Ashtor, 1992: 32). "As long as they needed the Jews, they welcomed them; but once they had achieved their goal and could dispense with the help of the Jews, they discarded them as one does the unwanted peel of a fruit already eaten" (Ibid., 39). Gradually, taxes were increased for both Christians and Jews. They were turned into a subordinate class, which, among the Christian population instigated conversion to Islam, even without the pressure of the Arab invaders, whereas among the Jewish population it instigated a messianic movement which gave rise to anti-Arab sentiments, restriction of the religious ritual to what was written in the Torah, and also emigration to a certain extent to the areas around the Mediterranean Sea. Their situation was particularly worsened by the unceasing conflict between the Arabs and the Berbers, which, at times, reached eruptive dimensions. This conflict diminished the Arabs' defensive strength and enabled the Christians as early as in the eighth century to regain part of the conquered territory, in the regions which are now part of north Portugal.

The situation in Muslim Spain changes with the coming of the Omayyad dynasty. ${ }^{6}$ The very first ruler of this dynasty manages, by brutal methods, to minimize the internal tribal conflicts and to establish a rule founded on law and

\footnotetext{
${ }^{6}$ The first ruler of this dynasty, Abdarrahman I, ruled from 756 to 788 . To the principles of his rule - adjustment to the existing situation and use of brutality against the rioters, also adhered his successors (Ashtor, 1992: 47-48).
} 
order. He raises the taxes, but at the same time establishes good relations with the Christians and the Jews, appointing them to important administrative positions, being aware that they cannot pretend to power, unlike the Arabs, whom he distanced little by little.

As for the Jews, Ashtor concludes, "the rule of Abdarrahman I was an era of communal growth and development" (Ibid., 50). His rule encouraged a large immigration to Spain of Arabic and Berber population from Africa, as well as Jews and other peoples from southern Europe. "In those days the Jews of Spain lived peacefully, were on a friendly footing with other religious groups, and even spread their religious concepts" (Ibid., 51).

However, when the reign was firmly established, in the western part of Spain, a legal and theological doctrine was adopted, whose distinctiveness was based upon conservatism and rigidity concerning matters of faith, and which required strictness in relation to the religious matters, to the ritual and the religious rules. ${ }^{7}$ It introduced severe legal measures against harm to the Islamic faith by the protected communities of Christians and Jews. Nonetheless, in the whole country, in the period of more than eight generations, up until the end of the Omayyad rule, the Jews were not persecuted. "The government did not oppress them or make any decrees to harm them..." (Ibid., 55). ${ }^{8}$ According to Ashtor, they refrained from any participation in politics, a position which played a significant role in maintaining such policy. "The loyal attitude of the Jewish populace toward the Omayyad government and the kindness with which the court treated Jews, this mutuality in their relationship constitutes a prominent motif in the history of the Jews in Spain at that time" (Ashtor, 1992:60).

The Omayyad kingdom was not wanting in frequent revolts of the Muslim population, conspiratorial activities of the Christian community, wars with the Christian kingdoms in the north and defensive activities against the Norman attacks. And yet, it managed, in the course of the ninth century, to rise as "one of the major powers in the Mediterranean basin", and owing to its geographic position and political stability, to become "a natural bridge between Christian Europe and Moslem Asia" (Ibid., 65). It succeeded in responding appropriately to the challenges it faced: to the Norman attacks it responded with the development of a navy, to the opportunities for trade growth with development of the monetary system, to the attacks from the north with construction of fortifications. However, it was the activities in the sphere of culture that were particularly significant achievements, when the intensive communication among the particular religious communities and sharing their intellectual interests resulted in the forming of a cultural system that connected in a syncretic whole the elements of the Muslim-Arab, Persian and Hellenistic cultures.

\footnotetext{
${ }^{7}$ In the eastern parts schools with moderate views were predominant.

${ }^{8}$ The same policy was pursued regarding the Christians (Ashtor, 1992: 59).
} 
In that middle period of Arabic rule, the Jews realized another benefit. Isolated within the framework of the Visigoth kingdom until then, with the Arabic rule, suddenly the doors to the surrounding countries opened wide, thus making the cultural achievements of the other Jewish communities available to them. At the same time, they were able to send their children to the Jewish educational centers in the Arabic countries in North Africa and the Middle East. So, they were faced with dilemmas when reconsidering the writings in the Talmud, imposed by the diaspora, that is, by the necessity of the Jewish communities to adjust to the social circumstances in which they existed. "The changes in circumstances wrought by the passage of time required them to modify Talmudic laws on occasion, interpreting them in harmony with the new situation" (Ashtor, 1992:123). They incline to the 'Babylonian Talmud', whose interpretations gradually suppress the old 'Jerusalem Talmud'.

"During the rule of Abdarrahman III in Cordoba (912-961) the Spanish Islamic state reached the peak of its power and glory. In that time there was abundance and great achievements, during which time the intellectual circles of the Muslims, the Jews and the Christians, under the patronage of Abdarrahman, contributed to the florescence of art, literature, astronomy and other cultural and scholarly disciplines. The Muslims showed great tolerance to the so-called biblical people and there were no obstacles for an easy and constant social communication with them on high social levels" (Smith, in: Esposito (Ed.), 2002:330). ${ }^{9}$

Since the end of the ninth century an open conflict occurred among the separate Muslim religious groups, which was also transferred to the relations between the non-Muslim communities, the Christians and Jews, as well as weakening of their internal cohesion resulting in development of heretic movements. ${ }^{10}$ A zealot movement emerged within the Christian community,

\footnotetext{
${ }^{9}$ The most obvious example of the opportunities of the Jews for social promotion is the position at the court of two Omayyad rulers, Abdarrahman III and Hakam II that was held by Hasdai ibn Shaprut (915-970), a scholar, physician and diplomat, who was officially the court doctor, but also held the office equal to a present-time minister of foreign affairs. In the context of his second position, he fostered establishing connections with all known Jewish communities, mediated for improvement of their conditions in the countries where they lived and for cultural ties, which resulted in Spain becoming the center of Jewish culture. His outstanding merit is the establishment of connections between the Jewish and Arab poets, which becomes apparent in the adoption of the Arabic metrics and themes by the Jewish poets. Due to his commitments, many Jewish poets, linguists and scholars settled in Cordoba and helped in the building of a school of theology in this city (Ashtor, 1992: 135-227).

${ }^{10}$ Within the Christian community a polemic is sparked regarding the divine and human nature of Christ and one of the interpretations was, what is called adaptionism, according to which Christ was born as a man and took the divine nature by being adopted by God, that is, he became a God-man. The other teaching is that he was a prophet sent by God to save the Jews (Ashtor, 1992:73,75).
} 
whose representatives, by calling the Muslims to conversion in Christianity, consciously put themselves in a position to be killed and thus acquire the status of martyrs. A zealot movement emerged also within Islam. Its main demand was not to impose conversion of non-Muslims to Islam, but to lower their social status - to retain them to second-class citizens. This concerned particularly the high officials, who were more numerous considering that the Christians and the Jews had on average higher education than the Muslims. "The demand for dismissal of non-Moslem officials became one of the important slogans of the Moslem zealots, and the struggle for the status in the service of the government ran like a scarlet thread throughout the history of the Jews and Christians in Islamic lands" (Ashtor, 1992:88).

The dismissal of non-Muslims from the government office began much earlier in the lands ruled by the Abbasids. In Omayyad Spain "Christian as well as Jewish officials apparently played an important role throughout the eighth and the first half of the ninth century without any enemies arising to oppose their status or threaten them with dire consequences" (Ibid., 89). Their removal became especially apparent at the end of the tenth century, when the deterioration of living conditions in the Muslim regions brought about religious fanaticism embodied in hostile relations to those who were not religiously likeminded. Then began a series of brutal campaigns against the Christians, involving "looting of churches and other Christian symbols" (Smith, in: Esposito (Ed.), 2002:332). At the same time, many other restrictions were introduced such as a ban on building non-Muslim shrines in territories where Muslims lived, the demolition of the newbuilt shrines, restrictions regarding public performance of the Christian rituals, as well as prohibitions against close communication in everyday life. The goal of each new rule for behavior was to emphasize the subordinate position in relation to the Muslim population. "Thus, ended the era of harmonious relations between the Muslims and the Christians in Spain and were replaced with impatience, prejudices and mutual distrust" (Ibid.). The Christians responded with the same impatience to the Muslim aggressive policy. The nearby Christian principalities started recurrent invasive attacks to the Muslim regions, which were aided by the local Christian population.

The dismissal of the Jews from the government office was not carried out to the same extent as that of the Christians. Unlike the rebellious Christian zealots, they remained loyal to the Muslim dominion, "the Jews, who were wholeheartedly loyal to the rulers, derived much benefit from this attitude" (Ashtor, 1992: 94). And, when the war with the Christian principalities to the north intensified, and the Christian rebellions became more frequent on the Omayyad territory, they took the side of the Mohammedans. Yet, as Baer observes, their position in individual principalities varied in accordance with their concrete political organization. "In a republic headed by aristocratic families there was no room for Jews statesmen. On the other hand, a monarch or other autocrat, the absolute ruler over an unfriendly population, would attract 
to his service Jews - the perpetual 'aliens' - on whose loyal support he could count in securing his regime" (Bauer, 1992: 32).

The disintegration of the Muslim kingdom was advanced by two parallel processes: the decentralizing tendencies of the Muslim nobility and the discontentment of the Christian population which takes on dimensions of a national liberation fight. ${ }^{11}$ The more the Muslim principalities weakened in the mutual conflicts, the stronger the desire of the Christians was to push them back. In this turbulent period, the neutral position of the Jews was often impossible, especially in situations when the two sides in the conflict were Muslims. This led to a wave of emigration to Africa, and also to Italy. At the same time, there was migration of the Christian population to the north.

\section{The religious tolerance in the Christian principalities in the advanced period of the Reconquista ${ }^{12}$}

"The war against their Moslem neighbors caused the Spaniards to become at once the most tolerant and the most fanatical people in medieval Christendom. The political objectives of the Reconquest opened up to the Jews broad opportunities for outwardly directed growth, but its religious motivation aroused the zeal of the Christians and subjected the internal religio-ethnic existence of the Jews to a severe trial" (Baer, 1992: 2-3).

Contrary to the ongoing decentralizing processes in the Muslim part of the peninsula, the Christian kingdoms, from the eleventh century onwards gradually started to connect in the context of the war they waged against the Muslim principalities. Their mutual connections continually narrowed, so that in the middle of the thirteenth century "there were in fact two great states: Castile - in the west and in the center and Aragon with Catalonia - in the east" (Altamira y Crevea, 1951: 140).

In the parts of Spain conquered by Christians, in the early period of the conquests, the established friendly relations between the Christian and Muslim population continued to be cherished. This peaceful period lasted in the ninth and tenth centuries, within which period migration occurred of the Muslim population from the southern Muslim principalities parallel with the migration of the Christian population. The first demand for change of their status came with the call for the First Crusade at the Clermont Council in 1095.

${ }^{11}$ Still, the political disorganization, followed by deterioration of the economic situation of the population, did not affect the sphere of culture and science. In the period when the political and economic power of the Muslim principalities gradually declined, "great Arab writers emerged, who became widely popular in Europe... in that period lived Averroes, the best known Arab philosopher, and also great Jewish writers of Muslim Spain - Avempace, Tufail, Ben Gabirol and others." (Altamira y Crevea, 1951: 221).

12 Reconquista is the period of Spanish history from 711 to 1492 , that is, from the beginning of the Arab conquest of the Iberian Peninsula, up to their final expulsion from Granada, the last Arab stronghold. 
After that the gradual shift of attitude towards Muslims and Jews began, which moved faster during the twelfth century, and intensified at the end of that century, by introducing regulations which were different in each city, but slowly merged into a single hostile attitude, when they were banished. Many bans were imposed on those who remained, the first one being the prohibition to live inside the city, forcing them to move outside of the city walls. In addition, limitations were placed regarding their practice of religious rituals. Their taxation increased dramatically. ${ }^{13}$ A continuous pressure for their moving out of the cities started, so that "by the middle of the twelfth century only a few of the poorest remained" (Baer, 1992: 49).

The position of the Jews in the newly conquered regions did not change in the beginning, which was a result of the needs of their practical experiences at that time. This even encouraged migration towards those regions. The Jews who settled in the Christian principalities in the north of the Iberian Peninsula (but also in other parts of Europe), were well accepted in the beginning due to "practical political needs" (Ibid., 47). They had built their own place in the social structure. Unlike the Christian and Muslim populations, who worked almost exclusively in agriculture, the Jews worked in the fields of craftsmanship and trade made them a part of "that social class which laid the foundations of urban life in Europe" (Baer, 1992: 79). They played a significant role when new cities were founded, in the establishment of the state administration, in maintaining the craftsmanship and trade thus providing finances for waging the wars. They "readily transferred their services to the new conquerors, whose power was rising" (Ibid., 48).

By putting themselves in the service of the new rulers, the Jews secured their right to live in their citadels within the city walls and to enjoy a complete autonomy in them, to organize their life quite independently of the city community or to participate in it.

Altamira y Crevea finds the reasons for the onset of hostility towards the Jews in the large material differences between them and the Christian population and the negative affections these differences were causing. Having in mind that the kings needed the services of the Jews, they themselves took no action against them, but the pressures they were exposed to by the Christian population led to decisions which deprived them of the established

${ }^{13}$ The position of the Muslims and the Jews did not deteriorate at the same pace. It worsened more quickly for the Muslims than for the Jews. The first indicator for this difference was the residential treatment: when a city was conquered, the Muslims were ordered to settle outside the city walls, whereas the Jews were not ordered to do so in the beginning. The Muslim places of worship were converted into Christian ones. The first case of such conversion of Jews synagogue happened in Barcelona in 1173. There were also cases of Muslim mosques being turned into synagogues (Baer, 1992:113). 
rights, that is, the rights they enjoyed during the Muslim rule. ${ }^{14}$ These pressures, as Baer concludes, were often instigated by the mutual trials which had more to do with the economy than with the faith. So, all trials between Christians and Jews were to be conducted by a Christian court, regulations were made which set different penalties for the same offence. The Jews and the newly converted were forbidden to hold administrative positions higher than those of the Christians, although that was not always possible to implement due to the practical political needs. ${ }^{15}$ They were slowly pushed out from many economic areas, which forced them to opt for moneylending, even though "this process, which turned the Jew into a professional moneylender had not yet been completed by the end of the twelfth century, and in Spain moneylending never did become a principal or characteristic Jewish occupation" (Baer, 1992: 85). When the Church prohibited the Christians from practicing moneylending, this prohibition was imposed in Spain in the thirteenth century, when the Jews became the only usurers.

The position of the Jews in the Christian principalities worsened to a great extent during the Crusades as the demands of the Christian population for limiting their economic activities were joined by the accusations of the Church against the heretics. Thus, the Fourth Council of the Lateran in 1215 proclaimed the unconverted Jews a danger and demanded their complete separation from the Christian community. At this council several decrees against the Jews were adopted, such as strictly fixed interest on loans, regulations for wearing clothes that would distinguish them from the Christians, wearing a special badge in addition to the special clothes, a prohibition against in a superior position over Christians, control over those who had converted their faith. At the following Lateran Councils, as well as with the special king's decrees, additional orders were issued, such as a special tax being imposed on the Jews, to be paid to the Church for their land, a prohibition against receiving inheritance from orthodox Christians and being banned from holding public office. Decrees were also issued concerning the behavior of the Christians towards the Jews, such as, a prohibition against socializing in order to avoid being exposed to Jewish religious propaganda, a prohibition against engaging Jews as lawyers and executors of their wills, or receiving medical care from Jewish doctors. However, some royal decrees were intended to protect, like the ban against the attack and plunder synagogues, as well as respecting the Sabbath and other Jewish holidays. Besides this, Jewish scholars were welcome at some

${ }^{14}$ The Jews were considered the possession of the king, so all rebellions of the Christian population against the king ended with violence against them, whose proportions sometimes reached a total destruction of their community (Baer, 1992: 89).

${ }^{15}$ Baer cites that the Christian rulers needed their linguistic services in particular - they dealt with the correspondence with the Muslim principalities. Due to their knowledge of the Arabic language, they served as translators and were engaged as diplomatic emissaries in the negotiations with the Arabs. (Baer, 1992: 54). 
royal courts, as the court of the Castilian king Alfonso $\mathrm{X}$ the Wise, who was interested in science himself and was a patron of scientists, including Jewish ones.

The Christian kingdoms established during the Reconquista period did not have a unified attitude towards the Jews. By the late thirteenth century, the Jews were completely dismissed from holding administrative and diplomatic office in the Kingdom of Aragon, whereas in Castile they were allowed to hold the office up until the end of the fourteenth century. Until then, Aragon managed to develop an efficient administrative apparatus, while Castile was still struggling to do so. In that kingdom they were given the office regulating state finances as this was forbidden for the Christian nobility by the Church, and the needs at that time required that they be involved in the diplomatic missions which called for knowledge of the Arabic language. In the Castilian cities they had the leading position in medical care. They were able to deal with craftsmanship and trade, and even to own land.

There were outcries against participation of the Jews in the public office by the population and even more by the Catholic Church, ${ }^{16}$ but the rulers were forced to ignore them, or, as in the case of Alfonso XI, to support the Jews secretly, but to express antisemitism publicly. With one act of 1340, this ruler ordered that borrowing money from Jews and Muslims is prohibited, entrusting the church to attend to the implementation of this order, but at the same time he guaranteed the right of Jews to possess land, and the right to buy land up to a certain value. ${ }^{17}$ This order had, in fact, significance only to the minority whose exclusive occupation was usury. To the majority of the Jewish population, who dealt with craftsmanship and trade, their standard of living constantly fell because the higher taxes, which did not allow them to compete with the Christian population. The taxes required of them drastically rose when, in the middle of the fourteenth century the dynastic wars were waged, and after those wars ended, their position improved or deteriorated, depending of the will of the new kings. Still, antisemitism grew among the masses.

Other new orders since the end of the fourteenth century constantly narrowed the communication between the Christian and non-Christian, Jewish and Muslim, populations and worsened the position of the latter. A specific problem were the converted Jews, the Marranos, who, due to their superior education, held important posts, not only in the state administration, but also in

${ }^{16}$ At the general council of Vienne (1311) and the local council in Zamora (1313) strict decisions were adopted regarding the exclusion of the Jews from public office, their entire segregation from the Christian population, their clothes, payment of tax to the Church, etc. (Baer, 1992: 310).

17 An order which banned borrowing money from Jews was adopted also in England where the consequences for them were disastrous. In Spain the consequences were not so tragic as money lending was not their sole occupation (Bauer, 1992: 360-361). 
the church. They were the ones the Inquisition totally exterminated, after having dealt with the problem with the Albigensians. ${ }^{18}$ The decision to direct the Inquisition toward them was adopted in 1482. However, this decision was expanded to encompass all Jews, because "as long as the Jews resided in Spain, Judaism was a clear and present danger to the Catholic faith" (Dimont, 2003: 228). This demand, which was submitted by the Spanish church to the Papal Throne was not approved by the Pope, but the fanatical royal couple, Queen Isabella and King Ferdinand, who gave permission for its implementation. Ultimately, "tens of thousands had been converted to Christianity at swordpoint. Those who had persisted in their faith had been expelled in 1492" (Kaplan, 2007: 299). Namely, "of the 150,000 Jews in Spain at that time, an estimated 50,000, whose ancestry dated back for fifteen hundred years in Spain, did not want to leave their homeland and paid the price for staying - conversion to Christianity" (Baer, 2003: 229). A few years later, in 1496, Portugal institutionalized the Inquisition and banished the Jews. And when the Jews were banished from Spain and Portugal, "Inquisition was turned against converted Moors, who were expelled from all of Spain in 1502" (Ibid.). In the following three centuries its victims become the Christians.

An observation of the subjects that were mostly the focus of the Inquisition leads to the conclusion that the motives for the persecution were predominantly of a financial nature. Victims of the persecution were by and large owners of large estates, and the sanctions used against them, among other things involved confiscation of the estates by the church. The Inquisition is the most obvious example of the significance of the economic factor for the Christian Church in building its attitude towards those who were not religiously likeminded and for the level of the manifested intolerance.

\section{Conclusion}

The economic factor in the relations among the individual religious communities in the diversity of political units in medieval Spain, is expressed in several modalities. The Visigoth Kingdom is an example of a minority conqueror with educational and cultural features lower than those of the conquered majority, whereby the necessitating the appointment of the latter to high administrative positions, which gives rise to anger among the victorious minority. In these situations, what lies behind the hostilities of a religious nature is the necessity of the ruling minority to keep the indigenous majority population in a subjugated position. In the situations where the new conquerors, like the Arab tribes, who also were a minority, introduce the principle of religious tolerance and free access to high administrative posts, the existing

${ }^{18}$ Albigensians (or Cathars) were a Christian sect, spread in southern France, against whom a Crusade was organized, one of the most fierce ones in the history of Crusades. 
educational and economic capacities of the indigenous population lead to their economic rise to be faster and thus again brings about envy and hostile feelings among the conquering minority. These negative sentiments intensify even more when the political units go through a process of disorganization and when some of them manage in the unfavorable circumstances more easily than others who have not attained the level of experience of the former. In the cases of the Christian principalities in the Reconquista period, the religious minorities, particularly the Jews, were well accepted until conditions were created for the majority Christian population to take over the roles for which they previously had neither economic nor educational capacities.

The influence of the political factor is of a more subtle nature and with a diversity of manifestations conditioned by the concrete political circumstances - stronger in states with aristocratic order, where competitive relations develop between the nobility of the majority community and the members of the minority one who have superior educational and cultural capacities; weaker in autocracies, where the ruler keeps the potential rivals of his own religious community at a distance by appointing the most significant positions to members of the minority religious communities who have no pretensions to seizing the royal power. Hence, the motives of the rulers, the nobility and the common people for accepting or rejecting the others do not always coincide, and in certain situations they are essentially different.

In the situations when the constellation of economic and political factors brings about creation of a climate in which the population belonging to the ruling class (majority or minority) develops a hostile attitude towards the other religious communities and requires restrictions of their access to high social positions, the religious factor plays the role of the trigger that sparks off the negative feelings towards the others. At least the occurrences in medieval Spain point to the fact that the demands of a religious nature are made when the dissatisfaction with the socio-economic position of the individual communities and the political conditions in a religiously varied society have reached a level that surpasses the limits of acceptability. Certainly, religious institutions have other motives as well, for defending their own and attacking others' religious concepts, which are not the object of this analysis. 


\section{Bibliography}

Ashtor, Eliyahu, 1992, The Jews in Moslem Spain, Vol. I, Philadelphia \& Jerusalem: The Jewish Publication Society

Алтамира-и-Кревеа, РафаелФ, 1951, Истори $\square$ Испании, Москва: Издателбство иностранной литератур

Baer, Yitzhak, 1992, A History of the Jews in Christian Spain, I, Philadelphia \& Jerusalem: The Jewish Publication Society

Dimont, Max I, 2003, Jews, God and History, New York: New American Library

Kaplan, Benjamin J., 2007, Divided by Faith, London: The Belknap Press of Harvard University Press

Neusner, Jacob \& Bruce Chilton (Eds.), 2008, Religious Tolerance in World Religions, West Conshohocken, Pennsylvania: Templeton Foundation

Смит, Џејн И., во: Еспозито Џон, Л. (Ред.), 2002, Оксфордска историја ислама, Београд: CLIO 
